\title{
ECO ENZYME PEMBERDAYAAN KELOMPOK PETANI DESA CIRANJANG CIANJUR TAHUN 2021
}

\author{
Ishak Ramli ${ }^{1}$ dan Yustina Peniyanti Jap ${ }^{2}$ \\ ${ }^{1}$ Program Studi Akuntansi, Universitas Tarumanagara, Jakarta \\ Email: ishakr@fe.untar.ac.id \\ ${ }^{2}$ Program Studi Akuntansi, Universitas Tarumanagara, Jakarta \\ Email: yustinap@fe.untar.ac.id
}

\begin{abstract}
This is a continuation PKM activity of the PKM carried out in 2016-2020. The PKM have successfully applied organik rice and developing financial institutions to help develop empowerment of farmers' group in Jatinunggal, Sindangsari village, Ciranjang, Cianjur.West Java. Farmers 'income has increased, but this has not yet made young farmers' return to the village, considering that the increase has not been enough. First, because the farmers' land is very small since it is distributed as inheritance. The second is it still a difficult and expensive organik fertilizer. In order to attract young human resources to increase their income, we introduced to manufacture, utilize and marketing eco enzyme products as organik fertilizers and as environmentally friendly organik cleaning products. We proposed producing and marketing eco enzyme as a solution to the income problem of the farmers group in Jatinunggal Sindangsari village, Ciranjang, Cianjur. One of the main benefits of this PKM activity is to give a solution to the rare and expensive organik fertilizer and increase understanding of the usefulness of eco enzyme products and market them in order to increase farmers' income. The implementation method is in collaboration with POKTAN in Jatinunggal, Sindangsari village, Ciranjang, Cianjur as a PKM partner through counseling and assistance in making Eco Enzyme, its benefits and how to market it. We have been doing the PKM activities from January to April 2021, in online meeting using WhatsApp group. As a result, in the first harvest POKTAN received additional income from saving organik fertilizer IDR 1,447,500 for one farmer and moreover they have additional income from selling Eco Enzyme products of IDR. 200,000. The total additional income is Rp. 1,647,500, and still they have inventory of 155 liters of Eco Enzyme products.
\end{abstract}

Keywords: Eco Enzyme, organik fertilizer, savings

\begin{abstract}
ABSTRAK
PKM ini merupakan kelanjutan dari PKM yang sudah dilakukan tahun 2016-2020. Kegiatan PKM sudah berhasil menerapkan padi organik dan Lembaga keuangan untuk membantu pengembangan pemberdayaan kelompok petani di Jatinunggal desa Sindangsari, Ciranjang, Cianjur. Pendapatan petani telah meningkat, namun hal ini belum membuat SDM muda petani kembali ke desa mengingat peningkatan belum mencukupi. Pertama karena tanah sawah milik sudah menjadi sangat kecil karena dibagikan sebagai warisan, kedua masih sulit dan mahalnya pupuk organik. Guna menarik minat SDM muda dalam menambah pendapatan mereka maka pengenalan, pembuatan, pemanfaatan, dan pemasaran produk eco enzyme sebagai pupuk organik dan sebagai produk pembersih organik ramah lingkungan, diusulkan sebagai solusi masalah pendapatan kelompok petani Jatinunggal desa Sindangsari, Ciranjang, Cianjur. Manfaat utama kegiatan PKM ini salah satunya adalah meningkatkan pemahaman kegunaan produk eco enzyme serta memasarkannya guna meningkatkan pendapatan petani. Metode pelaksanaan bekerja sama dengan POKTAN di Jatinunggal desa Sindangsari, Ciranjang, Cianjur sebagai mitra PKM melalui penyuluhan dan pendampingan pembuatan Eco Enzyme, manfaat serta bagaimana memasarkan nya. Kegiatan PKM secara daring pada Januari s/d April 2021. Hasilnya pada panen pertama POKTAN mendapatkan tambahan pendapatan dari penghematan pupuk organik dari satu petani sebesar Rp.1.447.500,- dan pendapatan dari penjualan produk Eco Enzyme sebesar Rp. 200.000, - Total tambahan pendapatan sebesar Rp. 1.647.500, - serta masih mempunyai persediaan produk Eco Enzyme sebanyak 155 l.
\end{abstract}

Kata Kunci: Eco Enzyme, pupuk organik, penghematan biaya.

\section{PENDAHULUAN}

\section{Analisis Situasi}

Keberadaan petani daerah kabupaten Cianjur, menjadi sangat strategis karena pertama, daerah kabupaten Cianjur merupakan daerah subur dan tanaman pangan, holtikultura, perkebunan, peternakan dan perikanan cocok dikembangkan di kabupaten Cianjur ini. Kedua, Sosio-kultur masyarakat sebagai petani memiliki ketekunan sebagai petani turun menurun. Ketiga, di canang kan pemerintah rencana pembangunan periode 2011-2031, kabupaten Cianjur menjadi lumbung 
padi Jawa Barat. Rencana pembangunan difokuskan kepada pengembangan sektor pertanian khusus nya pengembangan produk padi. Sasaran tersebut berkaitan dengan program ketahanan pangan sehingga pemda mentargetkan area seluas kurang lebih 98.637 ha sebagai kawasan pertanian (Cianjur Kabupaten, n.d.). Luas kawasan terbagi menjadi sub-sektor meliputi: holtikultura sebesar 43,53\%, perkebunan sebesar 34,67\% dan sub sektor lainnya sebesar 21,80\%. Mengacu pada program tersebut sudah selayaknya keberadaan petani menjadi sangat penting dan diharapkan akan semakin sejahtera sehingga menikmati kualitas hidup yang lebih baik.

Pengembangan agroculture, Kabupaten Cianjur memiliki potensi lokal sebagai partner pengembangan sektor pertanian. Secara geografis wilayah tersebut dekat dengan potensi pariwisata, seperti: kawasan Cipanas, Bogor dan Bandung. Sumber daya alam merupakan peluang bisnis bagi petani untuk membuat kolaborasi komoditas pertanian dengan pariwisata. Hasil sektor pertanian seperti: padi dan sayuran dapat ditingkatkan nilai ekonomisnya melalui pendekatan agro entrepreneurship. Inovasi usaha sektor pertanian perlu dilakukan untuk meningkatkan nilai tambah bagi hasil pertanian. Agro entrepreneurship mitra petani merupakan terobosan merubah pola pikir petani menjadi pelaku usaha agribisnis. Transformasi petani sebagai pelaku usaha memerlukan upaya dengan mengembangkan sinergi antara universitas dengan petani.

Pendekatan gagasan tersebut telah dilakukan dosen FEB universitas Tarumanagara sejak mulai tahun 2016 kepada kelompok tani Jatinunggal Desa Sindangjaya Kec. Ciranjang Kab. Cianjur melalui model agro entrepreneurship. Pengenalan akan padi organik dan pembentukkan koperasi Credit Union telah berjalan selama empat tahun. Petani bersama mitra PKM dosen FEB universitas Tarumanagara (dosen) diperkenalkan penanaman padi organik dan pendanaan nya dilakukan dengan sistem koperasi Credit Union. Hasil panen padi organik dibantu dipasarkan dosen. Selain itu Credit Union (CU) juga membantu para petani anggota CU untuk melakukan berbagai usaha baik dari segi tehnik maupun pendanaan dengan biaya yang lebih rendah dari bunga bank.

Permasalahannya banyak anak petani yang diharapkan menjadi petani muda sebagai generasi penerus tidak bersedia meneruskan pekerjaan atau usaha orang tua nya mengingat penghasilan menjadi petani tidak mencukupi kebutuhan mereka yang semakin meningkat. Kondisi eksisting kelompok tani Jatinunggal masih menghadapi masalah berkaitan dengan aspek ekonomi maupun sosial budaya. Pertama: Kelompok tani masih menghadapi keterbatasan sumber daya manusia muda yang menekuni sektor pertanian. Hanya sebagian kecil pengolahan lahan dilakukan oleh petani muda, mengingat pilihan sebagai pekerja atau pedagang di kota besar akan lebih menjanjikan. Keterbatasan luas tanah sawah yang di warisankan oleh petani makin sempit sehingga tidak memenuhi kebutuhan secara ekonomi. Kenyataan bahwa rata-rata luas tanah sawah petani sekitar 200-300 meter persegi.

Peningkatan pendapatan petani mitra PKM dosen Untar tahun 2016 hingga tahun 2020 melalui penanaman padi organik, namun ternyata masih terkendala dengan pupuk organik yang digunakan. Tanaman organik lebih tahan hama serta harga jual produk padi organik lebih tinggi dibandingkan dengan harga padi dengan pupuk kimia, namun tehnologi pembuatan pupuk organik masih menjadi hambatan bagi petani mitra. Pupuk organik cair masih agak sulit diperoleh dan harganya juga masih lumayan tinggi. Kondisi keterbatasan tenaga kreatif dalam mengembangkan potensi pertanian berdampak pada produktivitas dan pendapatan petani. Usia kelompok petani (Poktan) berasal dari generasi tua berusia antara 45-65 tahun sehingga cenderung lamban mengadopsi ide kreatif atau inovasi budidaya tanaman pangan dan holtikultura termasuk tehnologi pembuatan pupuk organik. Walaupun demikian banyak di antara generasi produktif Poktan Kampung 
Jatinunggal sangat antusias mengembangkan kreativitas sektor pertanian, seperti kelompok tani dipimpin oleh Ibu Sri Rahayu dan Bapak Adi Triyana.

Kedua: Pengelolaan keuangan petani Jatinunggal dilakukan melaui CU, ini mengatasi keterbatasan dana saat persiapan musim tanam, seperti: pupuk, bibit, obat-obatan, peralatan dan upah buruh tani. CU membantu mengatasi keterbatasan keuangan disebabkan oleh ketidakmampuan mengelola keuangan hasil panen. Hubungan petani-rentenir merugikan petani, terutama saat harga komoditas turun atau sedang mengalami penurunan produktivitas hasil panen. Kondisi tersebut menyebabkan selisih nilai diterima petani dengan biaya relatif tipis, dan pada akhirnya petani kesulitan membayar pinjaman.

Namun mengingat masih lemahnya pengelolaan keuangan melalui CU, maka CU terkendala dana yang masih belum kembali saat panen. Kesulitan ekonomi menyebabkan petani menggadaikan lahan kepada orang sekitar Kota Cianjur, sehingga banyak di antara mereka tidak memiliki lahan pertanian. Terobosan mengatasi masalah gadai lahan/sawah dapat diatasi melalui pendanaan dari CU dan masyarakat masih tetap eksis mengembangkan potensi pertanian, namun CU masih terkendala dengan kurang nya dana tersedia. Pertama belum bertambah nya anggota CU dan kedua belum kembali uang dari petani.

Ketiga: Kendala tata niaga atau mata rantai pemasaran produk pertanian dialami oleh Poktan. Pandemi covid 19 berdampak kepada keterbatasan pemasaran kepada pihak user, menyebabkan penjualan hasil pertanian seperti: gabah atau holtikultura kembali ditangani oleh pedagang/tengkulak, dengan harga cenderung rendah dan petani kurang menikmati hasil panen secara maksimal. Jika dikaitkan dengan analisis ekonomi pertanian, maka pandemi covid 19 mengembalikan tata niaga tersebut dan menurunkan nilai tawar petani.

Diversifikasi pertanian melalui penanaman padi organik menjaga harga komoditas pertanian. Poktan terbuka dalam pengembangan usaha pertanian melalui penanaman padi organik namun terkendala dengan pengadaan pupuk organik.

Hasil analisis situasi dengan pihak mitra Poktan Jatinunggal diwakili oleh Ibu Sri Rahayu dan Bapak Adi Triana, saat ini teridentifikasi masalah pupuk organik dan pemasaran produk padi organik ketika pandemi, serta penambahan dana bagi CU. Solusi mengatasi persoalan Poktan padi akan mendorong produktivitas petani dan akhirnya meningkatkan nilai tambah bagi petani. Pendekatan mengatasi masalah mitra dipertimbangkan dari berbagai ragam kehidupan masyarakat sehingga tidak menyinggung tradisi masyarakat atau kearifian lokal yang sudah terbentuk oleh masyarakat Jatinunggal Desa Sindangjaya. Berdasarkan analisis situasi tersebut, program Ipteks Bagi Masyarakat $\left(\mathrm{I}_{\mathrm{b}} \mathrm{M}\right)$ tahun 2021, memfokuskan Eco Enzyme pupuk organik kelompok petani (Poktan) padi Kampung Jatinunggal Desa Sindangjaya Kecamatan Ciranjang Kabupaten Cianjur.

\section{Permasalahan Mitra}

Persoalan eksisting Poktan padi Jatinunggal Desa Sindangjaya perlu diberikan solusi, agar kinerja atau produktivitas masyarakat petani lebih baik. Justifikasi tim pengusul dengan mitra diarahkan pada dua aspek prioritas utama, yaitu: aspek produksi Eco Enzyme dan aspek manajemen.

Pertama: Aspek produksi Eco Enzyme berkaitan dengan keterbatasan pupuk organik yang dan keterbatasan sumber daya manusia produktif. Keterbatasan sumber daya manusia produktif dilatarbelakangi oleh pengetahuan minim tehnologi. Upaya generasi muda menggeluti sektor pertanian dengan pengetahuan yang lebih maju. Upgrade informasi bagi petani dan petugas PPL 
pertanian dan petani sangat diperlukan, sehingga komoditas yang dibudidayakan sesuai dengan kebutuhan pasar (market oriented). Pengembangan hubungan kerjasama antara generasi petani muda, petugas penyuluh pertanian dan tim pengusul dilakukan untuk mengatasi permasalahan ini.

Kedua: aspek manajemen berkisar pengelolaan keuangan dan jaringan pemasaran sektor pertanian di masa pendemi. Masalah berkaitan dengan belum maksimal nya CU membantu pengelolaan keuangan karena kurang berkembang nya anggota CU Jatinunggal Desa Sindangjaya. Baik posisi sebagai petani, rentenir dan tengkulak merupakan bagian masyarakat yang belum tergabung dalam keanggotaan CU. Padahal sebagian besar pihak tersebut tinggal atau berasal sekitar Sindangjaya/Ciranjang, sehingga sudah terjalin hubungan kemasyarakatan yang baik sebelumnya. Karakter gotong royong, kekeluargaan dan kebersahajaan masyarakat pedesaan menyebabkan mereka saling menerima atau toleran. Pendekatan kepada ketiga pelaku sektor pertanian akan menemukan solusi secara win-win solution, sehingga terbentuk simbiosis mutualisma antara pihak tersebut.

Berdasarkan analisis situasi di atas, prioritas permasalahan mitra Poktan padi Jatinunggal Desa Sindangjaya Kabupaten Cianjur adalah:

1. Bagaimana cara meningkatkan nilai tambah komoditas melalui Eco enzyme dalam menanggulangi kendala ketersediaan dan harga pupuk organik Poktan Jatinunggal?

2. Bagaimana cara menambah ke anggotaan $\mathrm{CU}$ dengan mengelola hubungan saling menguntungkan antara pelaku sektor pertanian dan CU Poktan Jatinunggal?

\section{Solusi Permasalahan yang ditawarkan}

Berdasarkan diskusi mitra Poktan Jatinunggal Desa Sindangjaya Kec. Ciranjang, solusi ditawarkan oleh tim pengusul $\mathrm{I}_{b} \mathrm{M}$ untuk mengatasi mitra adalah:

Pertama: Aspek produksi didesain untuk mengatasi kesenjangan ekonomi dan sosial budaya dialami oleh Poktan Jatinunggal Desa Sindangjaya. Di samping itu untuk menekan kesenjangan minat petani generasi muda dengan generasi lama, sehingga di Kampung Jatinunggal Desa Sindangjaya tidak mengalami keterbatasan SDM produktif pada 5-10 tahun ke depan. Pendekatan sisi produksi akan merangsang kelompok generasi muda menekuni sektor pertanian secara kreatif dan inovatif. Fokus kegiatan ini menganalisis dari sisi ekonomi dan manajemen, sehingga model pendekatan mitra terfokus pada pembentukan wirausaha sektor pertanian untuk meningkatkan nilai tambah hasil pertanian, bukan menekankan pada teknologi pertanian. Pendekatan diarahkan dengan mensinergikan antara anggota petani Jatinunggal desa Sindangsari, Kec. Ciranjang, Cianjur dengan tim pengusul.

Solusi yang ditawarkan kepada mitra Poktan padi Jatinunggal Desa Sindangjaya adalah: Mengembangkan kewirausahaan berbasis produk eco enzyme untuk pertanian tanaman pangan atau agro entrepreneurship. Dasar pertimbangan model solusi adalah: adanya potensi sumber daya alam, sosio kultur masyarakat pertanian setempat serta peluang pasar saat ini, maka potensi Poktan padi Sindangjaya diarahkan pada agro entrepreneurship. Model pertanian hijau berbiaya rendah dengan mengoptimalkan pembuatan dan penggunaan eco enzyme oleh masyarakat desa setempat, serta memanfaatkan sumber bahan baku yang tersedia di sekitar desa. Memanfaatkan sampah kulit buah, sayur, dan eceng gondok guna membuat eco enzyme.

Kedua: Aspek manajemen didesain untuk mengelola hubungan kemasyarakat Kampung Jatinunggal Desa Sindangjaya menjadi solusi pengelolaan keuangan. Persoalan mitra Poktan padi Jatinunggal berhubungan dengan pengelolaan SDM, keterbatasan sumber dana dan akses 
pemasaran. Upaya mensinergikan antara petani sebagai produsen, rentenir sebagai pemberi pinjaman dan tengkulak sebagai distributor perlu dikelola dengan baik, agar menghasilkan nilai tambah secara optimal bagi ketiga pihak. Tata kelola stakeholder penting diperkenalkan kepada anggota Poktan, sehingga terjadi metaforfosis fungsi petani, rentenir, dan tengkulak menjadi kemitraan (partnership) dalam CU.

Solusi yang ditawarkan kepada mitra Poktan padi Jatinunggal Desa Sindangjaya adalah: Meningkatkan pengembangan lembaga pendanaan mikro (CU) yang sudah ada kepada pihak terlibat dalam usaha sektor pertanian. Bentuk realisasi tersebut dikaitkan dengan pemasaran produk pembersih ramah lingkungan dan sekaligus pupuk organik eco enzyme melalui masyarakat Sindangjaya. Tata kelola stakeholder sektor pertanian disentralkan pada penguatan struktur pendanaan petani, melalui penambahan anggota kemitraan dalam credit unions. Solusi kedua ini sebagai bentuk suport bagi solusi pertama, sehingga terbentuk keunggulan petani Jatinunggal Sindangjaya. Keunggulan ini akan menciptakan nilai tambah petani serta sebagai realisasi model ketahanan pangan. Hal ini diharapkan akan menambah anggota $\mathrm{CU}$, dan akan menambah modal CU.

\section{METODE PELAKSANAAN PKM Langkah-langkah Tahapan Pelaksanaan}

Berikut kegiatan PKM yang dilakukan:

a. Koordinasi dengan POKTAN Jatinunggal Desa Sindangjaya, Kec. Ciranjang, Kabupaten ianjur, Jawa Barat untuk mendapatkan persetujuan pelaksanaan kegiatan PKM yakni penentuan pertemuan pertama, bagaimana pertemuan daring dilaksanakan, aplikasi pertemuan daring, dan mekanisme kegiatan. Berhubung kesulitan penggunaan aplikasi untuk pertemuan daring, maka di sepakati aplikasi Whatsapp group sebagai aplikasi pertemuan daring. Diawali pertemuan pada tanggal 22 Agustus 2020 dengan beberapa arahan kegiatan PKM Eco enzyme.

b. Konfirmasi persetujuan dilanjutkan dengan langkah berikutnya. Pertemuan daring selanjutnya dilaksanakan tanggal 3, 7, 25, 27, 30 Janurai, 17 Februari, 2, 9, 11, 15, 26, 30 Maret, serta 9 April 2021, melakukan rapat tim secara virtual untuk menyelesaikan kegiatan PKM, dan bimbingan berdasarkan kesepakatan masing-masing.

c. Pengiriman proposal kegiatan ke ABDIMAS, LPPM UNTAR untuk mendapatkan persetujuan dan Surat Perjanjian Kerja sebagai dasar kontrak kerja dan monev, dilakukan pada tanggal 01 Februari 2021.

d. Kegiatan pembuatan eco enzyme sudah diawali sejak Agustus 2020. Kegiatan PKM yang sudah dilakukan sebelumnya selama 4 tahun memberi kemudahan bagi kami berkomunikasi dan memulai kegiatan baru. Hasil panen Eco enzyme sudah digunakan untuk pupuk organik dan tambahan cairan pembersih baik untuk cuci baju dan kebersihan kamar mandi serta peralatan lainnya termasuk untuk kebutuhan pribadi.

\section{HASIL DAN PEMBAHASAN}

Kegiatan PKM menghasilkan produk Eco Enzyme. Strategi memanfaatkan sampah organik guna memproduksi produk eco enzyme yang berguna dan ramah lingkungan, disamping untuk pupuk organik maupun juga untuk cairan pembersih lingkungan yang ramah lingkungan. Produk tersebut mengurangi logam berat, dan ion dalam tanah serta kadar ke asam an tanah (Ibrahim et.al., 2020; Lemboye et.al., 2020). Hasil test eco enzyme (EE) menunjukkan bahwa EE merupakan asam dan tidak mengandung ammonia, nitrogen, dan fosfor, sehingga EE dapat dimanfaatkan untuk menjadi alternatif metode untuk pengolahan air limbah. EE dapat mempercepat proses pencernaan kandungan organik (Verma et al., 2019). Pencampuran EE 10\% dalam air bersih efektif membantu 
penghilangan parameter pada air limbah seperti Total Suspended Solids (TSS), Total Dissolved Solids (TDS), minyak dan gemuk, Biological Oxygen Demand (BOD), Chemical Oxygen Demand (COD), dan chloride bisa sampai 99\%. (Joseph et al., 2020). Hal ini cocok untuk digunakan pada air di waduk pembangkit tenaga listrik PLN Cirata yang dimanfaatkan penduduk sekitar (Ciranjang; lokasi Mitra PKM)) untuk ternak ikan. Kegiatan memproduksi Eco enzyme merupakan dampak sinergi antara partikel dengan enzim sampah (Eco enzyme) dalam wadah biotransformasi limbah organik dalam sistem pengomposan. Ini menjadi alternative dalam pengomposan organik yang lebih murah dan mudah (Mandpe et al., 2021). Ini juga menjadi solusi untuk mengurangi sampah organik yang terdapat dilingkungan POKTAN.

Eco enzyme merupakan enzyme yang mampu untuk membatasi logam berat dalam tanah, menambah PH tanah atau mengurangi keasaman tanah, membunuh bakteri, microba, dan virus . Banyak digunakan dalam bencana gunung meletus, banjir, dan kebakaran dalam membantu mengurangi bateri, mikroba, dan virus. Air limbah di purify menjadi bersih dan sehat bebas dari kuman. Bahkan hasil produk eco enzyme (Garbage enzyme) bukan hanya dapat menyuburkan tanaman juga mempercepat pertumbuhannya, serta memiliki multi manfaat bagi masyarakat, sebagai penyembuh luka dan memudahkan pembersihan udara dan lingkungan (Susanto, 2020). Eco enzyme ini dimanfaatkan petani mengatasi masalah kesulitan mencari pupuk organik yang biasa digunakan pada penanaman padi organik di Jatinunggal desa Sindangsari, Ciranjang, Cianjur. Disamping itu biaya pembuatan yang lebih murah dibanding membeli pupuk organik cair.

Proses pembuatan eco enzyme dilakukan oleh para petani bersama Mitra PKM dengan mengolah sampah sayur dan kulit buah dengan gula aren serta air (Gambar 1). Komposisi 1 bagian gula aren, 3 bagian sampah sayur dan kulit buah, ditambah air sebanyak 10 bagian. Pencampuran dilakukan di dalam wadah plastik (biru). Kemudian ditutup dengan tutup kedap udara. Setiap minggu tutup wadah dibuka sebentar untuk mengeluarkan gas yang terbentuk dari fermentasi. Setelah 3 minggu tutup kedap udara tanpa dibuka sampai 3 bulan fermentasi. Setelah 3 bulan fermentasi hasil panen eco enzyme dimasukkan ke dalam botol plastik dan siap untuk dipakai atau dijual (Gambar 2)

\section{Gambar 1}

\section{Proses Pembuatan Eco Enzyme}

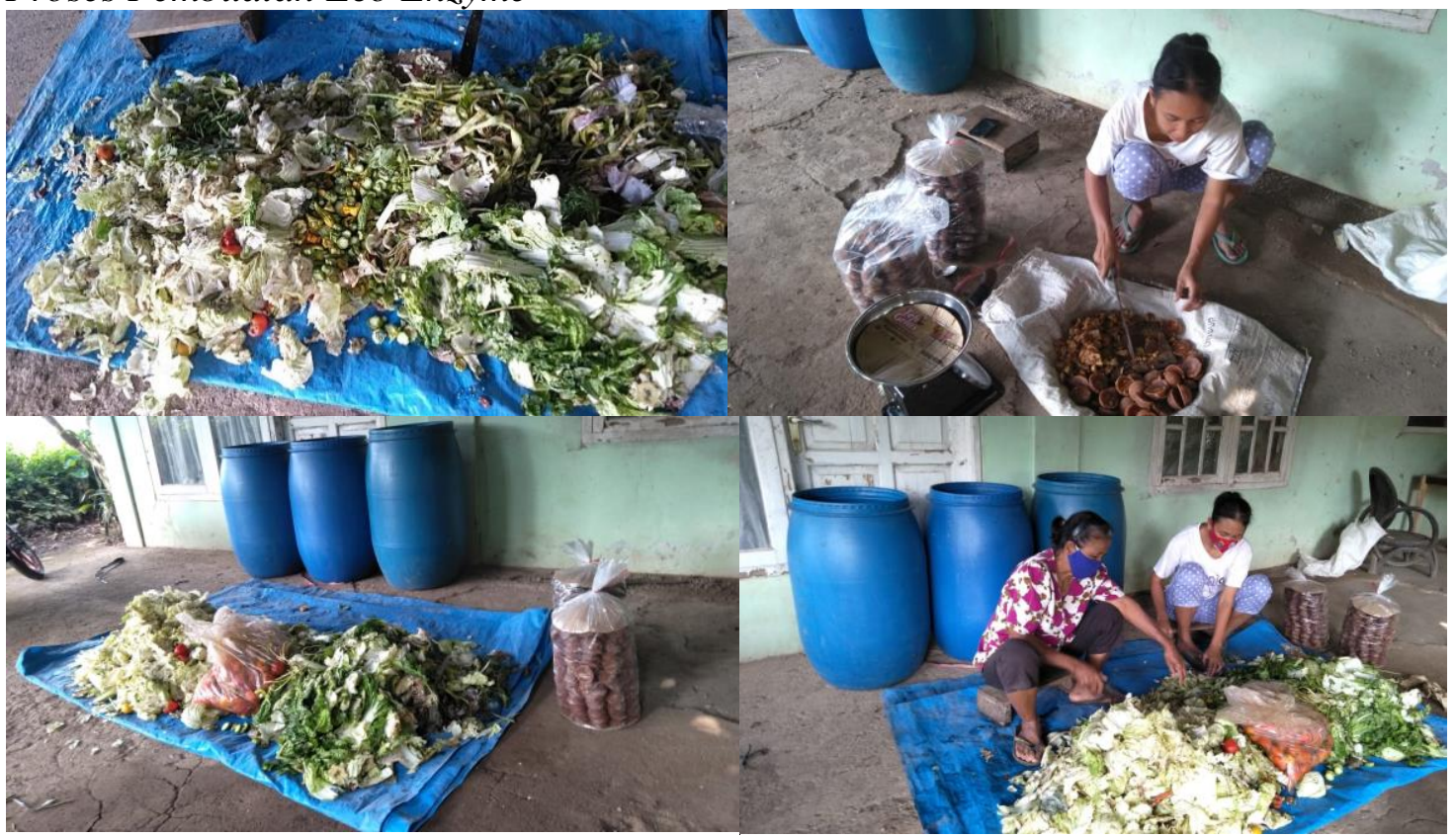




\section{Gambar 2}

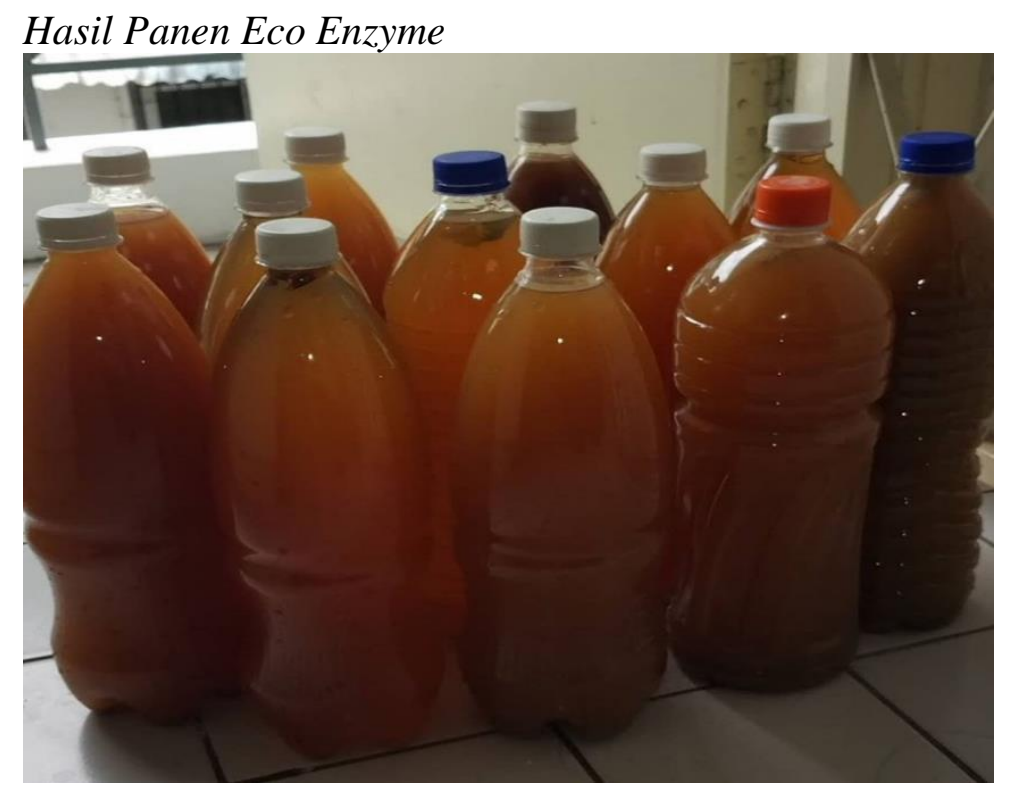

Hasil panen pertama produk eco enzyme sebanyak 205 1. Digunakan untuk pupuk organik sebanyak 35 l, dijual produk eco enzyme, dan digunakan untuk Rumah Tangga sebanyak 51.

Analisis luaran pembuatan Eco enzyme baik untuk pupuk organik maupun dijual serta sisa hasil persediaan sebagai berikut:

Panen Pertama :

- Hasil panen = 2051 eco enzyme

- digunakan untuk pupuk organik sebanyak 351 untuk seorang petani.

- Dibanding dengan bila menggunakan pupuk organik cair yang dibeli:

- Penghematan biaya :

- Bila pupuk organik cair dibeli: 35 @ Rp. 45.000,- = Rp. 1.575.000,-

- Biaya produksi Eco enzyme: 35 @ Rp. 6.500,- = Rp. 227.500,-

- Penambahan pendapatan dari penghematan = -Rp. 1.347.500,-

Pendapatan Kedua :

- Hasil penjualan :terjual 101 @ Rp. 26.500,- = Rp. 265.000,-

- Biaya produksi $101=10$ @ Rp. $6.500=$ Rp. 65.000,-

- Tambahan pendapatan $=$ = Rp. 200.000,-

Total tambahan pendapatan Petani (satu orang) = Rp. 1.547.500,-

Penghematan biaya rumah tangga $\quad=$ Rp. 100.000,-

Grand Total penambahan pendapatan petani $\quad=$ Rp. 1.647.500,-

Sementara masih terdapat persediaan sebanyak 1501 Eco Enzyme yang siap dijual.

Berdasarkan pengalaman tersebut diidentifikasi terdapat penambahan pendapatan petani sebesar Rp. 1.647.500,- namun terkendala oleh pemahaman produk eco enzyme dan kegunaan nya menyebabkan penambahan pendapatan ini masih membutuhkan waktu mungkin satu - dua tahun kedepan untuk menjadi penambahan pendapatan bagi para petani lainnya. Demikain juga masih menjadi kendala bagi penambahan anggota Koperasi Credit Union melalui strategi produk eco 
enzyme ini. Kegiatan ini sebagai uji coba dan pengalaman baru bagi petani Jatinunggal sehingga membutuhkan proses evaluasi dan pemantauan dilakukan sampai 1-2 tahun ke depan.

\section{KESIMPULAN DAN SARAN \\ Kesimpulan}

Dua prioritas masalah mitra Poktan padi Jatinunggal Desa Sindangjaya diidentifikasi setiap kegiatan dan spesifikasi luaran sebagai berikut:

Pertama, penambahan pendapatan dengan memproduksi Eco enzyme sebagai pupuk organik dan sebagai bahan pembersih cair untuk rumah tangga dan pribadi, serta pengobatan luka. Di identifikasi keberhasilan kegiatan PKM ini meningkatkan pendapatan petani pada panen pertama sebesar Rp. 1.647.500,-. Kegiatan ini sebagai solusi memecahkan masalah pupuk organik dalam aspek produksi yang sangat melekat dengan konteks ekonomi maupun sosial budaya. Dasar pemikiran ide tersebut adalah Jatinunggal desa Sindangjaya, Ciranjang, Cianjur memiliki potensi memproduksi eco enzyme. Pertama bahan baku berupa kulit buah atau daun organik mudah didapat. Di Jatinunggal desa Sindangsari terdapat waduk PLN yang banyak dimanfaatkan sebagai budidaya ikan, namun pada waduk tersebut memproduksi eceng gondok yang sangat banyak. Ini dapat digunakan sebagai bahan baku pembuatan eco enzyme.

Komoditas eco enzyme dapat diarahkan untuk memasok kebutuhan petani ikan pada waduk yang sering terkendala kotor nya air waduk, kebutuhan hotel, restoran atau cafe sekitar kawasan wisata tersebut sebagai bahan pembunuh bakteri dan virus serta menghilangkan bau dengan produk (non kimia) ramah lingkungan. Kreativitas usaha pertanian dikembangkan kepada produsen produk sehat anti kimia (eco enzyme).

Program agro entrepreneurship dapat meningkatkan penghasilan petani dan sebagai bentuk stimulan agar generasi muda tertarik membangun kekuatan ekonomi pedesaan melalui eco enzyme dan tanaman pangan. Model agro entrepreneurship mampu mengelola usaha sektor pertanian atau agribisnis (agroindustri), dengan dukungan teknologi pertanian atau teknologi tepat guna. Pendekatan wirausaha melekat dengan inovasi pengembangan bisnis sektor pertanian dengan mengintegrasikan tiga komponen penting, yaitu: kekuatan lembaga penelitian \& pengembangan, spirit kewirausahaan serta venture capital sebagai penyedia modal bagi pemula.

Kedua, membina kerja sama kemitraan antara pelaku sektor pertanian. Pihak tersebut baik sebagai petani, rentenir maupun tengkulak dapat diberdayakan secara bersama untuk mengembangkan anggota Credit Union (CU) sehingga meningkatkan tersedia nya dana pada CU. Pemberdayaan ketiga pihak tersebut diharapkan agar saling mampu bertahan dan dapat saling menghidupi tanpa harus merugikan.

\section{Saran}

Saran eco enzyme dapat dikembangkan di daerah lain sebagai produk ramah lingkungan dan serba guna.

\section{Ucapan Terima Kasih (Acknowledgement)}

Ucapan terimakasih kami kepada LPPM UNTAR up. Manajer ABDIMAS atas dukungan pendanaan untuk kegiatan ini dan kepada pihak POKTAN Desa Sindangjaya Kec. Ciranjang Kabupaten Cianjur Propinsi Jawa Barat, sebagai mitra dalam kegiatan PKM yang dilaksanakan ini atas kerja sama membangun desa, serta kepada asisten pelaksana PKM atas kelancaran komunikasi dan laporan kegiatan PKM. 


\section{REFERENSI}

Cianjur Kabupaten. (n.d.). Website Resmi Cianjur. https://cianjurkab.go.id/

Ibrahim, S., Mohd, N. S., Ahmad, M. A., Zainal, B. S., Danaee, M. \& Jamadon, N. (2020). Integrated system technology of pome treatment for biohydrogen and biomethane production in Malaysia. Applied Sciences, 10, 951. doi:10.3390/app10030951

Joseph, A., Joji, J. G., Prince, N. M., Rajendran, R., Nainamalai, M. \& Vishnu. (December 24, 2020). Domestic wastewater treatment using garbage enzyme. Proceedings of the International Conference $n n$ Systems, Energy \& Environment (ICSEE). https://ssrn.com/abstract=3793057 or http://dx.doi.org/10.2139/ssrn.3793057

Lemboye, K., Lateef, M. A., Moghal, A. A. B., Chittoori, B. C. S., Mohammed, S. A. S. \& Almajed, A. (2020). efficacy of enzymatically induced calcium carbonate precipitation in the retention of heavy metal Ions. Sustainability, 12, 7019. doi:10.3390/su12177019

Mandpe, A., Yadav, N., Paliya, S., Tyagi, L., Yadav, B. R., Singh, L., Kumar, S. \& Kumar, R., (2021). Exploring the synergic effect of fly ash and garbage enzymes on biotransformation of organik wastes in in-vessel composting system. Bioresource Technology, 322, 124557

Susanto, E. (29 Desember 2020). Eco enzyme penyembuh aneka luka, kebersihan lingkungan dan udara.

Verma, D., Singh, A. N., Shukla, A.K. (July 2019). Use of garbage enzyme for treatment of waste water. International Journal of Scientific Researchand Review, 7(7), 201-205. 